medRxiv preprint doi: https://doi.org/10.1101/2020.10.30.20215301; this version posted November 3, 2020. The copyright holder for this preprint (which was not certified by peer review) is the author/funder, who has granted medRxiv a license to display the preprint in It is made available under a CC-BY-NC-ND 4.0 International license .

\title{
Remdesivir-based therapy improved recovery of patients with COVID-19 in the SARSTer multicentre, real-world study
}

Robert Flisiak1*\#, Dorota Zarębska-Michaluk2*, Aleksandra Berkan-Kawińska3, Magdalena Tudrujek-Zdunek4, Magdalena Rogalska1, Anna Piekarska3, Dorota Kozielewicz5, Krzysztof Kłos6, Marta Rorat7,8, Beata Bolewska9, Anna Szymanek-Pasternak10, Włodzimierz Mazur11, Beata Lorenc12, Regina Podlasin13, Katarzyna Sikorska14, Barbara OczkoGrzesik15, Cezary Iwaszkiewicz16, Bartosz Szetela17, Paweł Pabjan2, Małgorzata Pawłowska5, Krzysztof Tomasiewicz4, Joanna Polańska18, Jerzy Jaroszewicz15.

*equal contribution

\# Corresponding author: Prof. Robert Flisiak, Department of Infectious Diseases and Hepatology, Medical University of Bialystok, ul. Zurawia 14, 15-540, Bialystok, Poland. Tel./fax: +48 857416921. Email: robert.flisiak1@gmail.com

1 Department of Infectious Diseases and Hepatology, Medical University of Białystok, Białystok, Poland

2 Department of Infectious Diseases, Jan Kochanowski University, Kielce, Poland

3 Department of Infectious Diseases and Hepatology, Medical University of Łódź, Łódź, Poland

4 Department of Infectious Diseases and Hepatology, Medical University of Lublin, Lublin, Poland

5 Department of Infectious Diseases and Hepatology, Faculty of Medicine, Collegium Medicum in Bydgoszcz, Nicolaus Copernicus University, Poland

6 Department of Infectious Diseases and Allergology, Military Institute of Medicine, Warsaw, Poland

7 Department of Forensic Medicine, Wrocław Medical University, Wrocław, Poland

8 First Infectious Diseases Ward, Gromkowski Regional Specialist Hospital in Wrocław, Wrocław, Poland.

9 Department of Infectious Diseases, University of Medical Sciences, Poznań, Poland

10 Department of Infectious Diseases and Hepatology, Wrocław Medical University, Wrocław, Poland

11 Clinical Department of Infectious Diseases in Chorzów, Medical University of Silesia, Katowice, Poland

12 Pomeranian Center of Infectious Diseases, Department of Infectious Diseases, Medical University of Gdańsk, Gdańsk, Poland

13 Hospital of Infectious Diseases in Warsaw, Warsaw, Poland

14 Department of Tropical Medicine and Epidemiology, Medical University of Gdańsk,

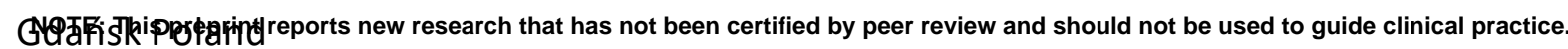


medRxiv preprint doi: https://doi.org/10.1101/2020.10.30.20215301; this version posted November 3, 2020. The copyright holder for this preprint (which was not certified by peer review) is the author/funder, who has granted medRxiv a license to display the preprint in It is made available under a CC-BY-NC-ND 4.0 International license .

15 Department of Infectious Diseases in Bytom, Medical University of Silesia, Katowice, Poland

16 Department of Rheumatology and Osteoporosis, Jozef Strus Hospital in Poznań, Poland

17 Department of Infectious Diseases, Liver Diseases and Acquired Immune Deficiencies, Wrocław Medical University, Wrocław, Poland

18 Department of Data Science and Engineering, Silesian University of Technology, Gliwice, Poland 
medRxiv preprint doi: https://doi.org/10.1101/2020.10.30.20215301; this version posted November 3, 2020. The copyright holder for this preprint (which was not certified by peer review) is the author/funder, who has granted medRxiv a license to display the preprint in It is made available under a CC-BY-NC-ND 4.0 International license.

\begin{abstract}
Background: Remdesivir (RDV) is the only antiviral drug registered currently for treatment of COVID-19 after a few clinical trials with controversial results. The purpose of this study was to evaluate the effectiveness and safety of RDV in patients with COVID-19 in real world settings.
\end{abstract}

Methods: Patients were selected from 1496 individuals included in the SARSTer national database; 122 of them received therapy with RDV and 211 were treated with lopinavir/ritonavir (LPV/r)-based therapy. The primary end-point of effectiveness was clinical improvement in the ordinal 8-point scale, which was defined as a 2-point decrease from baseline to 7, 14, 21 and 28 days of hospitalization. The secondary end-points of effectiveness included: death rate, rate of no clinical improvement within 28 days of hospitalization in the ordinal scale, rate of the need for constant oxygen therapy, duration of oxygen therapy, rate of the need for mechanical ventilation, total hospitalization time, and rate of positive RT PCR for SARS-CoV-2 after 30 days.

Findings: Significantly higher rates of clinical improvement, by $15 \%$ and $10 \%$ respectively, were observed after RDV treatment compared to LPV/r at days 21 and 28 . The difference between regimens increased with worsening of oxygen saturation $\left(\mathrm{SpO}_{2}\right)$ and depending on the baseline score from the ordinal scale. Statistically significant differences supporting RDV were also noted regarding the rate of no clinical improvement within 28 days of hospitalization and hospitalization duration in patients with baseline $\mathrm{SpO}_{2} \leq 90 \%$. In the logistic regression model only the administration of remdesivir was independently associated with at least a 2-point improvement in the ordinal scale between baseline and day 21.

Interpretation: In conclusion, data collected in this retrospective, observational, real world study supported use of remdesivir for treatment of SARS-CoV-2 infection particularly in patients with oxygen saturation $\leq 95 \%$.

Key words: COVID-19, SARS-CoV-2, therapy, remdesivir, 
medRxiv preprint doi: https://doi.org/10.1101/2020.10.30.20215301; this version posted November 3, 2020. The copyright holder for this preprint (which was not certified by peer review) is the author/funder, who has granted medRxiv a license to display the preprint in It is made available under a CC-BY-NC-ND 4.0 International license .

Funding: Polish Association of Epidemiologists and Infectiologists.

Ethics Committee: The study was retrospective, non-interventional, based on data collected in national database, so it does not require approval of Ethics Committee.

Authors contribution: All authors had full access to all the data in the study and take responsibility for its integrity and the accuracy of the analysis. RF and DZM were responsible for the study concept, design, acquisition of data, verification of the underlying data and drafting the manuscript. JJ and JP were responsible for statistical analysis. All other authors were responsible for the acquisition of data and were involved in the final mansucript preparation.

\section{Declaration of interests}

RF reports grants from Abbvie, Gilead Merck, personal fees from Gilead, Abbvie, Merck, Roche, and non-financial support from Abbvie, Gilead and Merck outside the submitted work.

DZM, PP reports personal fees from Gilead and Abbvie, outside the submitted work.

JJ reports personal fees from Gilead, Abbvie, Bausch Health, Merck, Promed, Roche and nonfinancial support from Abbvie, Gilead and Merck outside the submitted work.

KT reports personal fees from Gilead, Abbvie, Merck, Promed, Roche and non-financial support from Abbvie, Gilead and Merck outside the submitted work.

KS reports personal fees from Gilead, Abbvie, Merck, outside the submitted work ASP, RP, BS reports personal fees from Gilead, outside the submitted work.

$A B K, J P, B B, M R P, K K, M P, A P, D K, W M, M T Z, C I, M R, B L, B O G$ declare no competing interests. 
medRxiv preprint doi: https://doi.org/10.1101/2020.10.30.20215301; this version posted November 3, 2020. The copyright holder for this preprint (which was not certified by peer review) is the author/funder, who has granted medRxiv a license to display the preprint in It is made available under a CC-BY-NC-ND 4.0 International license .

\section{Introduction}

In December of 2019, a new pathogen associated with an outbreak of respiratory tract infections was discovered in Wuhan, China. It was identified as a novel coronavirus termed severe acute respiratory syndrome coronavirus (SARS-CoV-2) closely related to already known betacoronaviruses responsible for epidemics named with the acronyms SARS and MERS (Middle East respiratory syndrome). The outbreak of the disease it causes, named coronavirus disease 2019 (COVID-19), was announced a global pandemic by the World Health Organization (WHO) in March 2020. The clinical spectrum of SARS-CoV-2 infection ranges from asymptomatic or mild self-limited respiratory tract disease to severe progressive pneumonia leading to acute respiratory distress syndrome (ARDS), and death due to multi-organ failure. At the start of the epidemic, only supportive care was available, but the rapid worldwide spread of COVID-19 has raised a desperate need to invent an antiviral agent active against SARS-CoV-2. At the beginning, the search for effective therapy focused on drug repurposing and new uses for approved agents with confirmed activity against other viruses. Among them, a compound of lopinavir and ritonavir (LPV/r) was identified. Lopinavir acting as an inhibitor of a human immunodeficiency virus (HIV) protease, co-administered with ritonavir to increase its bioavailability, was demonstrated to have in vitro activity against both SARS-CoV and MERS-CoV viruses $[1,2,3,4,5]$. The positive impact of LPV/r on clinical outcome and reduction of the viral load in nasopharyngeal swabs were documented in the patients participating in the open-label study performed the outbreak of SARS in 2003. Three case reports and one retrospective study described the use of LPV/r in patients with MERS, suggesting improved clinical outcome [6, 7]. Hence, due to the structural similarity of all betacoronaviruses, the relevance of LPV/ $r$ in the treatment of COVID-19 was considered. To answer the question of whether this antiviral agent works in SARS-CoV-2 infection, Cao et al. [8] performed an urgent open-label randomized clinical trial in Wuhan, the epicentre of the outbreak, to evaluate the LPV/r efficacy in patients diagnosed with COVID-19. Nevertheless, the study results were disappointing and no superiority of LPV/ $r$ therapy in terms of clinical improvement, duration of hospitalization, or period of viral RNA detectability as compared to standard of care ( $\mathrm{SoC}$ ), was documented. The only difference of statistical significance was observed in the median time to clinical improvement calculated after exclusion of patients with early death; however, the authors themselves called this difference "modest" [8]. No positive impact of LPV/ $r$ therapy was documented in critically ill patients with SARS-CoV-2 related pneumonia treated in the intensive care unit and also in patients with mild to moderate form of COVID-19 compared to SoC or adjuvant therapy $[9,10,11]$.

Since the process of discovery, testing and registration of a new antiviral drug is long-lasting and cost-intensive with an uncertain chance of success, attention has been paid to investigational drugs with potential activity against SARS-CoV-2. The most promising among them is remdesivir (RDV), a prodrug of an adenosine nucleoside analogue which terminates viral RNA synthesis by inhibition of RNA-dependent RNA polymerase (RdRP), with established dosing and safety profile. The primary clinical indication of RDV was Ebola virus disease (EVD). However, despite the encouraging results of the in vivo efficacy evaluation in an animal model, the randomized phase III clinical trial did not clearly confirm the relevance 
medRxiv preprint doi: https://doi.org/10.1101/2020.10.30.20215301; this version posted November 3, 2020. The copyright holder for this preprint (which was not certified by peer review) is the author/funder, who has granted medRxiv a license to display the preprint in It is made available under a CC-BY-NC-ND 4.0 International license.

of RDV in humans and then this investigational agent was shelved [12]. There was a renewed interest in RDV concerning SARS-CoV and MERS-CoV infections and confirmed in vitro and animal models activity against the family of coronaviruses has raised hope for effective application in the treatment of COVID-19 [13]. Since the inhibitory effect on the recently emerged novel coronavirus was demonstrated in vitro, clinical trials and compassionate use programs have started, and the WHO announced the launch of a trial that would include one group of patients treated with remdesivir [14, 15, 16]. Finally, based on findings from phase III clinical trials ACTT-1 and SIMPLE-severe, on 1st May 2020 RDV received emergency use authorization (EUA) for the treatment of COVID-19 issued by the Food and Drug Administration (FDA) $[17,18,19]$. Subsequent conditional licences in different countries worldwide have made remdesivir the first approved antiviral agent for the treatment of COVID-19.

The purpose of the study is evaluation of the effectiveness and safety of RDV administered to patients with COVID-19 in real-world settings. Lopinavir/ritonavir based regimen was used as a comparator instead of undefined and inperfect concept of "standard of care", applied usually in COVID-19 studies.

\section{Material and Methods}

The study population consisted of patients selected from 1496 individuals included in the SARSTer national database. This ongoing project, supported by the Polish Association of Epidemiologists and Infectiologists, is a national real-world experience study assessing treatment in patients with COVID-19. Patients whose data were collected in the SARSTer database were treated in 30 Polish centres, between 1 March and 31 August 2020. The decision about the treatment regimen was taken entirely by the treating physician with respect to current knowledge and recommendations of the Polish Association of Epidemiologists and Infectiologists [20, 21]. The current analysis included 333 adult patients who received regimens based on the antiviral drugs remdesivir or lopinavir/ritonavir administered for therapy of COVID-19. RDV was administered intravenously once a day with a loading dose of $200 \mathrm{mg}$ and later a maintenance dose of $100 \mathrm{mg}$ for 5-10 days. LPV/r was administered orally in a dose of $400 / 100 \mathrm{mg}$ every 12 hours for up to 28 days. LPV/r was used mostly at the beginning of the pandemic and due to documented later lack of effectiveness is considered as a comparator for RDV in this study.

Data were entered retrospectively and submitted online by a web-based platform operated by "Tiba" sp. z o.o. Parameters collected at baseline included age, gender, body mass index (BMI), comorbidities and concomitant medications, clinical status at admission, additional medication dedicated to COVID-19, and adverse events. Baseline clinical status at admission to hospital was classified as asymptomatic, symptomatic stable with oxygen saturation $\left(\mathrm{SpO}_{2}\right)>95 \%$, symptomatic unstable with $\mathrm{SpO}_{2}$ 91-95\%, symptomatic unstable, $\mathrm{SpO}_{2} \leq 90 \%$ or acute respiratory distress syndrome (ARDS).

The primary end-point of treatment effectiveness was clinical improvement in the ordinal scale based on WHO recommendations modified to fit the specificity of the national health care system. Improvement was defined as a 2-point decrease from baseline to 7, 14, 21 and 
medRxiv preprint doi: https://doi.org/10.1101/2020.10.30.20215301; this version posted November 3, 2020. The copyright holder for this preprint (which was not certified by peer review) is the author/funder, who has granted medRxiv a license to display the preprint in It is made available under a CC-BY-NC-ND 4.0 International license.

28 days of hospitalization. The ordinal scale was scored as follows: 1 . unhospitalized, no activity restrictions; 2 . unhospitalized, no activity restrictions and/or requiring oxygen supplementation at home; 3 . hospitalized, does not require oxygen supplementation and does not require medical care; 4 . hospitalized, requiring no oxygen supplementation, but requiring medical care; 5 . hospitalized, requiring normal oxygen supplementation; 6 . hospitalized, on non-invasive ventilation with high-flow oxygen equipment; 7. hospitalized, for invasive mechanical ventilation or ECMO; 8. death.

The secondary end-points of effectiveness included: death rate, rate of no clinical improvement within 28 days of hospitalization in the ordinal scale, rate of the need for constant oxygen therapy, duration of oxygen therapy, rate of the need for mechanical ventilation, total hospitalization time, and rate of positive RT PCR for SARS-CoV-2 after 30 days of hospitalization.

\section{Statistical analysis}

The results are expressed as mean \pm standard deviation (SD) or $n(\%)$. P values of $<0.05$ were considered to be statistically significant. The significance of difference was calculated by chisquare or Fisher's exact test for nominal variables and by Mann-Whitney $U$ and Kruskal-Wallis ANOVA for continuous variables. Univariate comparisons were calculated by GraphPad Prism 5.1 (GraphPad Software, Inc., La Jolla, CA). Forward stepwise logistic regression models with the Bayesian information criterion (BIC) as a model selection criterion were performed with $\geq 2$-point decrease in the ordinal scale between baseline and day 21 of hospitalization as the dependant variable. Among independent variables tested were age, sex, BMI, diabetes, coronary artery disease, baseline classification and baseline score in ordinal scale, as well as therapy with RDV, LPV/r, tocilizumab, dexamethasone, chloroquine/hydroxychloroquine, heparin, dexamethasone, convalescent plasma and azithromycin. Logistic regression models were calculated by use of R and MATLAB (MathWorks, MA, USA).

\section{Results}

Among 333 patients included in the study 122 received therapy with RDV and 211 were treated with LPV/r. Groups were balanced regarding gender, age and BMI, but in both arms, there was a predominance of males (Table 1). Patients treated with RDV more frequently demonstrated a symptomatic unstable course of the disease with $\mathrm{SpO}_{2} \leq 95 \%$ at admission to the hospital (69\%) compared to those receiving LPV/r (57\%), but the difference was not statistically significant. Prevalence of accompanying diseases was higher among patients treated with RDV, but the difference was significant only regarding ischaemic heart disease (Table 1). During the therapy with RDV additional medication more frequently included dexamethasone, convalescents plasma, and low molecular weight heparin, whereas LPV/r was more frequently administered together with chloroquine and azithromycin (Table 1).

As shown in Figure 1, proportions of categories of ordinal scale were balanced at the baseline between the two treatment groups. The rate of patients discharged from the hospital was similar on days 7 and 14 , but became higher in patients treated with RDV on days 21 and 28 (Figure 1). Differences in the score in the ordinal scale between particular 
medRxiv preprint doi: https://doi.org/10.1101/2020.10.30.20215301; this version posted November 3, 2020. The copyright holder for this preprint (which was not certified by peer review) is the author/funder, who has granted medRxiv a license to display the preprint in It is made available under a CC-BY-NC-ND 4.0 International license.

time points and baseline at admission to the hospital are shown in Figure 2. Clinical improvement measured using an ordinal scale demonstrated significantly higher rates after RDV treatment compared to LPV/r at weeks 21 and 28 and the difference was $15 \%$ and $10 \%$ respectively (Table 2). Additional analysis of clinical improvement using the ordinal scale was carried out depending on the baseline oxygen saturation at admission to hospital. Difference between regimens increases with worsening of oxygen saturation during the analysis on days 14, 21 and 28 (Table 2). A similar tendency was demonstrated depending on the baseline score from the ordinal scale. On the other hand, the rate of no improvement within 28 days was significantly higher after treatment with LPV/r (Table 2). This tendency was also demonstrated in analysis carried out with regard to baseline oxygen saturation or baseline ordinal score, and differences between two regimens increased with either decline of oxygen saturation or decrease of baseline ordinal score (Table 2). As shown in Table 2 the rate of no clinical improvement within 28 days of hospitalization and hospitalization duration was significantly lower in patients treated with RDV if they had baseline $\mathrm{SpO} 2 \leq 90 \%$.

In the logistic regression model in patients receiving RDV or LPV/r only the administration of remdesivir was independently associated with at least a 2-point improvement in the ordinal scale between baseline and day 21 , while older age and use of tocilizumab were negative predictors of response (Table 3 ). Interestingly, in patients with older age tocilizumab on the contrary improved likelihood of response.

Patients treated with LPV/r experienced significantly more adverse events (39\%) than those treated with RDV (20\%). The most frequent among those receiving LPV/r were diarrhoea (25\%), nausea (8.5\%), vomiting (6.2\%) and prolongation of the QT interval (5.2\%). Patients treated with RDV most frequently experienced elevation of aminotransferases (9.8\%), and other adverse events occurred sporadically (Table 2).

\section{Discussion}

Since $1^{\text {st }}$ May 2020, the FDA's emergency use authorization has allowed for remdesivir to be distributed and administered intravenously to treat COVID-19 in patients with severe disease. It has become possible due to the promising results of phase III clinical trials. Hence, the antiviral agent which failed to live up to expectation in the treatment of Ebola virus disease has become a hope for those infected with SARS-CoV-2. Conditional approvals issued in other countries and regions worldwide in the wake of the decision of the United States federal agency has enabled the treatment of RDV in patients with low blood oxygen levels or needing oxygen therapy or more intensive breathing support. However, giving access to a new potential therapy, the need for further research to evaluate the safety and effectiveness of the RDV was highlighted.

Since June 2020 remdesivir has also been available in Poland. Therefore we aimed to assess the efficacy and tolerability of RDV in real-world experience. LPV/r based regimen was used as a comparator due to its antiviral mode of action because both agents act by inhibiting viral proteins. We used this idea instead of undefined and inperfect concept of "standard of care", applied usually in COVID-19 studies, which can be recognized in the different way depending on treating center and period of pandemic. As the lack of benefit of LPV/r treatment compared to SoC was documented by Cao et al. [8] in patients with COVID-19-related pneumonia, in the current analysis we assumed the efficacy of LPV/r at the level close to placebo. The majority 
medRxiv preprint doi: https://doi.org/10.1101/2020.10.30.20215301; this version posted November 3, 2020. The copyright holder for this preprint (which was not certified by peer review) is the author/funder, who has granted medRxiv a license to display the preprint in It is made available under a CC-BY-NC-ND 4.0 International license.

of patients receiving RDV presented symptomatic unstable status with $\mathrm{SpO}_{2} \leq 95 \%$ at admission to the hospital (68\%). Using the ordinal scale widely applied in COVID-19 trials, we confirmed that RDV treatment was associated with significantly greater clinical improvement, defined as a two-point decrease in disease severity, by day 21 ( $86 \%$ vs. 71\%, p=0.001) and 28 (93\% vs. $83 \%, p=0.01$ ) compared to the $\mathrm{LPV} / \mathrm{r}$ arm. A significant difference at day 21 was observed regardless of the baseline score at admission to the hospital. The detailed analysis carried out considering the baseline oxygen saturation demonstrated a statistically significant difference among unstable patients, by day 21 for individuals with $\mathrm{SpO}_{2} \leq 90 \%$, and by day 28 for those with baseline $\mathrm{SpO}_{2} 91-95 \%$. The possible reason for the lack of difference by day 7 and 14 could be an effect of national regulation used until 31 August 2020, which in practice ordered hospitalization of the majority of patients for at least 14 days irrespective of treatment and clinical improvement.

Hence, our findings supported results from clinical trials, including those based on which the decision of EUA was made $[17,18,19]$. Patients with COVID-19 without reduced oxygen levels included in the SIMPLE-moderate phase III trial treated with RDV for 5 days were significantly more likely to have clinical improvement as compared to those receiving SoC alone, whereas for those randomized to the 10-day regimen a significant difference was not documented [22]. Similar results were obtained for patients with the severe form of COVID-19 defined as oxygen saturation $<95 \%$ while breathing ambient air or receiving oxygen support, treated with RDV in SIMPLE-severe phase III trial. Clinical improvement was demonstrated in $65 \%$ and $54 \%$ of patients receiving RDV for 5 and 10 days, respectively [18]. In both trials the assessment was performed at a time point different from ours, at day 11 for moderate and 14 for severe disease $[18,19,22]$. Notably, the comparison concerning patients with severe COVID-19 was not randomized and performed not within one study but between individuals on RDV treatment included in the SIMPLE-severe phase III clinical trial and concurrent retrospective real-world cohort study on SoC only [19]. Moreover, not all patients treated with RDV were included in the comparative analysis. After exclusion of Italian patients on RDV due to lack of comparative individuals on SoC from the real world experience (RWE) study, 74\% of those treated with RDV fulfilled criteria for clinical improvement as compared to $59 \%$ among the SoC cohort at day $14(p<0.001)$.

This imperfection was not shared by another phase III study ACTT-1 designed as a doubleblind, randomized and placebo-controlled trial. The preliminary results of this study confirmed RDV superiority relative to placebo (normal saline solution) in shortening the time to recovery, 11 vs. 15 days. Patients were assessed daily using an ordinal scale and the primary outcome measure was the first day on which the patient reached one of the three lowest levels in the scale meaning "not hospitalized with or without limitation of activities" and "hospitalized not requiring supplemental oxygen and ongoing medical care". However, the trial is not completed and final data are still expected [17]. Also, data from the compassionate-use programme confirmed the benefit of RDV treatment in patients with severe COVID-19, including those on invasive ventilation, reporting a $68 \%$ rate of clinical recovery [23]. Unlike the above-mentioned studies, no positive impact of RDV relative to placebo was documented in patients with the severe form of COVID-19 with baseline oxygen saturation < 95\% included in the randomized, double-blind multicentre phase III clinical trial conducted in Wuhan [14]. However, it should be noted that enrolment was prematurely terminated due to control of the epidemic in Wuhan, and hence the study was underpowered. 
medRxiv preprint doi: https://doi.org/10.1101/2020.10.30.20215301; this version posted November 3, 2020. The copyright holder for this preprint (which was not certified by peer review) is the author/funder, who has granted medRxiv a license to display the preprint in It is made available under a CC-BY-NC-ND 4.0 International license.

The current analysis demonstrated benefit from RDV treatment as compared to LPV/r in terms of secondary end-points. Among them, a statistically significant difference was found for rate of no improvement within 28 days in the ordinal scale, whereas for the remaining parameters, including death rate, the need for constant oxygen therapy and its duration, the need for mechanical ventilation, rate of positive RT PCR for SARS-CoV-2 after 30 days, and hospitalization length, the positive impact of RDV without statistical significance was documented. Interestingly, most striking and significant effect of RDV on the length of hospitalization was observed in patients with baseline SpO2 who needed on average 7 days less of hospital stay. Our findings on mortality are in line with results achieved in the clinical trials SIMPLE and ACTT-1 and an observational study conducted among patients with cancer $[17,19,22,23]$.

Unfortunately, detailed comparison regarding remaining outcomes is not possible due to different end-points and time of assessment [17, 19, 22].

The tolerability profile of remdesivir in the current analysis was in accordance with clinical trials with the most frequent transient aminotransferases elevation reported in nearly $10 \%$ of patients. LPV/ $r$ was frequently responsible for transient diarrhoea, well known from experience in HIV infected patients, which did not affect significantly clinical status of patients and duration of hospitalization.

We are aware of the limitations of our study. Among them, the impact of other therapeutic agents dedicated to COVID-19 should be pointed out. Baseline characteristics demonstrated the different distribution of patients with respect to concomitant drugs with a significantly higher rate of dexamethasone, convalescent plasma and low molecular weight heparin, and a lower rate of chloroquine and azithromycin among patients treated with RDV. To eliminate this imbalance as a confounding factor we performed analysis using logistic regression, demonstrating that in patients receiving RDV or LPV/r only the administration of remdesivir was independently associated with at least a 2-point improvement in the ordinal scale at day 21. Importantly, in this model we could not prove an additional independent beneficial effect of dexamethasone or convalescent plasma on this endpoint, while the use of tocilizumab was only beneficial in older patients.

Other limitations of the current analysis are related to the RWE nature of the research, including its observational nature and retrospective electronic data capture with possible data entry errors. Unfortunately, we were not able to increase the number of patients in the study because of changed national regulations, which allowed the release of a patient from the hospital without RT PCR negativisation, which could significantly affect ordinal scale interpretation. However, the major strength of the study is collection of data from a realworld, heterogeneous population, thus being representative for routine practice, and a clearly defined comparator, unlike in some other studies, which usually used an undefined SoC. Interestingly, we observed that addition of tocilizumab can improve the likelihood of improvement, which supports our previous experience with this drug, but possible use of combined therapy of remdesivir and tocilizumab needs further study [24].

In conclusion, data collected in this retrospective, observational, real-world study with antivirals as a leading therapy in two competing arms supported the use of remdesivir compared to lopinavir/ritonavir for treatment of SARS-CoV-2 infection, particularly in patients with oxygen saturation $\leq 95 \%$. 
medRxiv preprint doi: https://doi.org/10.1101/2020.10.30.20215301; this version posted November 3, 2020. The copyright holder for this preprint (which was not certified by peer review) is the author/funder, who has granted medRxiv a license to display the preprint in It is made available under a CC-BY-NC-ND 4.0 International license .

\section{References}

1. Yamamoto N, Yang R, Yoshinaka Y, et al. HIV protease inhibitor nelfinavir inhibits replication of SARS-associated coronavirus. Biochem Biophys Res Commun. 2004; 318(3):719-725. doi:10.1016/j.bbrc.2004.04.083

2. Chen $\mathrm{F}$, Chan $\mathrm{KH}$, Jiang $\mathrm{Y}$, et al. In vitro susceptibility of 10 clinical isolates of SARS coronavirus to selected antiviral compounds. J Clin Virol. 2004; 31(1): 69-75. doi:10.1016/j.jcv.2004.03.003

3. Chu CM, Cheng VC, Hung IF, et al. Role of lopinavir/ritonavir in the treatment of SARS: initial virological and clinical findings. Thorax. 2004; 59(3): 252-256. doi:10.1136/thorax.2003.012658

4. deWilde AH, Jochmans D, Posthuma CC, et al. Screening of an FDA-approved compound library identifies four small-molecule inhibitors of Middle East respiratory syndrome coronavirus replication in cell culture. Antimicrob Agents Chemother. 2014; 58(8): 4875-4884. doi:10.1128/AAC.03011-14.

5. Chan JF, Yao Y, Yeung ML, et al. Treatment With Lopinavir/Ritonavir or Interferon- $\beta 1 \mathrm{~b}$ Improves Outcome of MERS-CoV Infection in a Nonhuman Primate Model of Common Marmoset. J Infect Dis. 2015; 212(12): 1904-1913. doi:10.1093/infdis/jiv392

6. Kim UJ, Won EJ, Kee SJ, Jung SI, Jang HC. Combination therapy with lopinavir/ritonavir, ribavirin and interferon- $\alpha$ for the Middle East respiratory syndrome. Antivir Ther. 2016; 21(5): 455-459. doi:10.3851/IMP3002

7. Spanakis N, Tsiodras S, Haagmans BL, et al. Virological and serological analysis of a recent Middle East respiratory syndrome coronavirus infection case on a triple combination antiviral regimen. Int J Antimicrob Agents. 2014; 44(6): 528-532.

doi:10.1016/j.ijantimicag.2014.07.026

8. Cao B, Wang Y, Wen D, et al. A Trial of Lopinavir-Ritonavir in Adults Hospitalized with Severe Covid-19. N Engl J Med. 2020; 382(19): 1787-1799. doi:10.1056/NEJMoa2001282

9. Lecronier M, Beurton $\mathrm{A}$, Burrel $\mathrm{S}$, et al. Comparison of hydroxychloroquine, lopinavir/ritonavir, and standard of care in critically ill patients with SARS-CoV-2 pneumonia: an opportunistic retrospective analysis. Crit Care. 2020; 24(1): 418. Published 2020 Jul 11. doi:10.1186/s13054-020-03117-9

10. Cai Q, Yang M, Liu D, et al. Experimental Treatment with Favipiravir for COVID-19: An Open-Label Control Study [published online ahead of print, 2020 Mar 18]. Engineering (Beijing). 2020; 10.1016/j.eng.2020.03.007. doi:10.1016/j.eng.2020.03.007

11. Kim JW, Kim EJ, Kwon HH, et al. Lopinavir-ritonavir versus hydroxychloroquine for viral clearance and clinical improvement in patients with mild to moderate coronavirus disease 2019. Korean J Intern Med. 2020;10.3904/kjim.2020.224. doi:10.3904/kjim.2020.224 [published online ahead of print, 2020 Jun 16] 
medRxiv preprint doi: https://doi.org/10.1101/2020.10.30.20215301; this version posted November 3, 2020. The copyright holder for this preprint (which was not certified by peer review) is the author/funder, who has granted medRxiv a license to display the preprint in It is made available under a CC-BY-NC-ND 4.0 International license .

12. Mulangu S, Dodd LE, Davey RT Jr, et al. A Randomized, Controlled Trial of Ebola Virus Disease Therapeutics. N Engl J Med. 2019; 381(24): 2293-2303. doi:10.1056/NEJMoa1910993

13. Sheahan TP, Sims AC, Graham RL, et al. Broad-spectrum antiviral GS-5734 inhibits both epidemic and zoonotic coronaviruses. Sci Trans/ Med. 2017; 9(396): eaal3653. doi:10.1126/scitranslmed.aal3653

14. Wang, M., Cao, R., Zhang, L. et al. Remdesivir and chloroquine effectively inhibit the recently emerged novel coronavirus (2019-nCoV) in vitro. Cell Res. 2020; 30, 269-271. https://doi.org/10.1038/s41422-020-0282-0

15. Lamb YN. Remdesivir: First Approval. Drugs. 2020; 80(13): 1355-1363. doi:10.1007/s40265-020-01378-w

16. WHO Public health emergency SOLIDARITY trial of treatments for SARS-COV-2 infection in hospitalized patients. ISRCTN registry. doi. last accessed. 2020 doi: 10.1186/ISRCTN83971151

17. Beigel JH, Tomashek KM, Dodd LE, et al. Remdesivir for the Treatment of Covid-19 Preliminary Report. N Engl J Med. 2020; NEJMoa2007764. doi:10.1056/NEJMoa2007764 [published online ahead of print, 2020 May 22]

18. Goldman JD, Lye DCB, Hui DS, et al. Remdesivir for 5 or 10 Days in Patients with Severe Covid-19. N Engl J Med. 2020;NEJMoa2015301. doi:10.1056/NEJMoa2015301 [published online ahead of print, 2020 May 27]

19. Olender SA, Perez KK, Go AS, et al. Remdesivir for Severe COVID-19 versus a Cohort Receiving Standard of Care. Clin Infect Dis. 2020;ciaa1041. doi:10.1093/cid/ciaa1041 [published online ahead of print, $2020 \mathrm{Jul} 24$ ]

20. Flisiak R, Horban A, Jaroszewicz J, et al. Management of SARS-CoV-2 infection: recommendations of the Polish Association of Epidemiologists and Infectiologists as of March 31, 2020. Pol Arch Intern Med. 2020; 130: 352-357. doi:10.20452/pamw.15270,

21. Flisiak R, Horban A, Jaroszewicz J, et al. Management of SARS-CoV-2 infection: recommendations of the Polish Association of Epidemiologists and Infectiologists. Annex no. 1 as of June 8, 2020. Pol Arch Intern Med. 2020; 130: 557-558. doi:10.20452/pamw.15424

22. Spinner CD, Gottlieb RL, Criner GJ, et al. Effect of Remdesivir vs Standard Care on Clinical Status at 11 Days in Patients With Moderate COVID-19: A Randomized Clinical Trial. JAMA. 2020; 324(11): 1048-1057. doi:10.1001/jama.2020.16349

23. Grein J, Ohmagari N, Shin D, et al. Compassionate Use of Remdesivir for Patients with Severe Covid-19. N Engl J Med. 2020; 382(24): 2327-2336. doi: 10.1056/NEJMoa2007016.

23. Rivera DR, Peters S, Panagiotou OA, et al. Utilization of COVID-19 Treatments and Clinical Outcomes among Patients with Cancer: A COVID-19 and Cancer Consortium (CCC19) Cohort Study. Cancer Discov. 2020 Jul 22. doi: 10.1158/2159-8290.CD-20-0941. Epub ahead of print. PMID: 32699031. 
medRxiv preprint doi: https://doi.org/10.1101/2020.10.30.20215301; this version posted November 3, 2020. The copyright holder for this preprint (which was not certified by peer review) is the author/funder, who has granted medRxiv a license to display the preprint in It is made available under a CC-BY-NC-ND 4.0 International license

24. Tomasiewicz K, Piekarska A, Stempkowska-Rejek J, et al. Tocilizumab for patients with severe COVID-19: a retrospective, multi-center study. Expert Rev Anti Infect Ther. 2020. doi: 10.1080/14787210.2020.1800453. [published online ahead of print, 2020 Aug 1] 
medRxiv preprint doi: https://doi.org/10.1101/2020.10.30.20215301; this version posted November 3, 2020. The copyright holder for this preprint (which was not certified by peer review) is the author/funder, who has granted medRxiv a license to display the preprint in It is made available under a CC-BY-NC-ND 4.0 International license .

Table 1

Characteristics of patients included in the study

\begin{tabular}{|l|c|c|c|}
\hline & $\mathrm{RDV}$ & $\mathrm{LPVr}$ & $\mathrm{p}$ \\
\hline $\mathrm{n}$ & 122 & 211 & \\
\hline females, $\mathrm{n} / \%$ & $43 / 35 \%$ & $85 / 40 \%$ & 0.41 \\
\hline males, $\mathrm{n} / \%$ & $79 / 65 \%$ & $126 / 60 \%$ & \\
\hline age, mean $\pm \mathrm{SD}$ & $58.7 \pm 14.5$ & $56.1 \pm 15.4$ & 0.15 \\
\hline $\mathrm{BMI}$, mean $\pm \mathrm{SD}$ & $29.3 \pm 4.5$ & $28.2 \pm 5.1$ & 0.05 \\
\hline Baseline clinical status at the admission to hospital & & & \\
\hline asymptomatic, $\mathrm{n} / \%$ & $1 / 0.8 \%$ & $7 / 3.3 \%$ & 0.27 \\
\hline symtomatic stable, $\mathrm{SpO}_{2}>95 \%, \mathrm{n} / \%$ & $38 / 31 \%$ & $83 / 39 \%$ & 0.16 \\
\hline symtomatic unstable, $\mathrm{SpO}_{2}$ 91-95\%, $\mathrm{n} / \%$ & $52 / 43 \%$ & $70 / 33 \%$ & 0.10 \\
\hline symtomatic unstable, SpO $\mathrm{S}_{2} \leq 90 \%, \mathrm{n} / \%$ & $30 / 25 \%$ & $49 / 23 \%$ & 0.79 \\
\hline acute respiratory distress syndrome (ARDS), $\mathrm{n} / \%$ & $1 / 0.8 \%$ & $2 / 0.9 \%$ & 1.00 \\
\hline Accompanying diseases & & & \\
\hline hypertension & $65 / 53 \%$ & $101 / 48 \%$ & 0.36 \\
\hline ischemic heart disease & $17 / 14 \%$ & $13 / 6 \%$ & 0.03 \\
\hline other cardiovascular diseases & $14 / 11 \%$ & $14 / 7 \%$ & 0.15 \\
\hline diabetes & $29 / 24 \%$ & $38 / 18 \%$ & 0.26 \\
\hline chronic obliterative pulmonary disease & $4 / 3 \%$ & $7 / 3 \%$ & 1.00 \\
\hline asthma & $4 / 3 \%$ & $4 / 2 \%$ & 0.47 \\
\hline tumors & $6 / 5 \%$ & $10 / 5 \%$ & 1.00 \\
\hline Additional medication dedicated to COVID-19 & & & \\
\hline chloroquine, $\mathrm{n} / \%$ & $7 / 5.7 \%$ & $153 / 73 \%$ & $<0.001$ \\
\hline hydrochloroquine, $\mathrm{n} / \%$ & $2 / 1.6 \%$ & $14 / 6.6 \%$ & 0.06 \\
\hline tocilizumab, $\mathrm{n} / \%$ & $27 / 22 \%$ & $34 / 16 \%$ & 0.19 \\
\hline covalescents plasma, $\mathrm{n} / \%$ & $17 / 14 \%$ & $13 / 6.2 \%$ & 0.03 \\
\hline low molecular weight heparin - prophylactic doses, $\mathrm{n} / \%$ & $109 / 89 \%$ & $137 / 65 \%$ & $<0.001$ \\
\hline low molecular weight heparin - therapeutic doses, $\mathrm{n} / \%$ & $9 / 7.4 \%$ & $13 / 6.2 \%$ & 0.65 \\
\hline dexamethason, $\mathrm{n} / \%$ & $31 / 25 \%$ & $18 / 8.5 \%$ & $<0.001$ \\
\hline azithromycin, $\mathrm{n} / \%$ & $10 / 8 \%$ & $37 / 18 \%$ & 0.02 \\
\hline
\end{tabular}


medRxiv preprint doi: https://doi.org/10.1101/2020.10.30.20215301; this version posted November 3, 2020. The copyright holder for this preprint (which was not certified by peer review) is the author/funder, who has granted medRxiv a license to display the preprint in

Table 2.

Effectiveness and safety of treatment with remdesivir compared to lopinavir/ritonavir.

\begin{tabular}{|c|c|c|c|c|c|c|c|}
\hline \multicolumn{3}{|l|}{ End point } & $\begin{array}{l}\text { follow- } \\
\text { up } \\
\text { period } \\
\text { (days) }\end{array}$ & $\begin{array}{l}\text { Remdesivir } \\
(\mathrm{N}=122)\end{array}$ & $\begin{array}{l}\text { Lopinavir/ } \\
\text { ritonavir } \\
(\mathrm{N}=211)\end{array}$ & OR $(95 \% \mathrm{Cl})$ & $\mathbf{P}$ \\
\hline \multirow{28}{*}{$\begin{array}{l}\text { Clinical } \\
\text { improvement, } \\
\text { ( } \geq 2 \text { points } \\
\text { decrease })\end{array}$} & \multirow{4}{*}{\multicolumn{2}{|c|}{ All patients }} & 7 & $2 / 122(1.6)$ & $11 / 211(5.2)$ & $\mathrm{OR}=0.30(0.07 ; 1.39)$ & 0.14 \\
\hline & & & 14 & $56 / 122(46)$ & $87 / 211(41)$ & $\mathrm{OR}=1.21(0.77 ; 1.90)$ & 0.42 \\
\hline & & & 21 & $105 / 122(86)$ & $149 / 211(71)$ & OR=2.57 (1.42; 4.65) & 0.001 \\
\hline & & & 28 & $113 / 122(93)$ & $175 / 211(81)$ & OR=2.58 $(1.20 ; 5.57)$ & 0.01 \\
\hline & \multirow[t]{12}{*}{ Depending on $\mathrm{SpO}_{2}$} & \multirow[t]{4}{*}{$>95 \%$} & 7 & $1 / 38(2.6)$ & $7 / 83(8.4)$ & $\mathrm{OR}=0.29(0.04 ; 2.47)$ & 0.43 \\
\hline & & & 14 & $17 / 38(45)$ & $37 / 83(45)$ & $\mathrm{OR}=1.01(0.47 ; 2.18)$ & 1.00 \\
\hline & & & 21 & $34 / 38(89)$ & $68 / 83(82)$ & $\mathrm{OR}=1.88(0.58 ; 6.09)$ & 0.42 \\
\hline & & & 28 & $37 / 38(97)$ & $79 / 83(95)$ & $\mathrm{OR}=1.87(0.20 ; 17.35)$ & 1.00 \\
\hline & & \multirow[t]{4}{*}{$91-95 \%$} & 7 & $0 / 52(0)$ & $2 / 70(2.9)$ & $\mathrm{OR}=0.26(0.01 ; 5.55)$ & 0.51 \\
\hline & & & 14 & $28 / 52(54)$ & $34 / 70(49)$ & $\mathrm{OR}=1.23(0.60 ; 2.53)$ & 0.59 \\
\hline & & & 21 & $47 / 52(90)$ & $54 / 70(77)$ & $\mathrm{OR}=5.17(1.10 ; 24.22)$ & 0.09 \\
\hline & & & 28 & $50 / 52(96)$ & $58 / 70(83)$ & OR=5.17 (1.10;24.22) & 0.02 \\
\hline & & \multirow[t]{4}{*}{$\leq 90 \%$} & 7 & $1 / 30(3.3)$ & $2 / 49(4.1)$ & $\mathrm{OR}=0.81(0.07 ; 9.34)$ & 1.00 \\
\hline & & & 14 & $10 / 30(33)$ & $12 / 49(24)$ & $\mathrm{OR}=1.54(0.57 ; 4.19)$ & 0.44 \\
\hline & & & 21 & $22 / 30(73)$ & $23 / 49(47)$ & OR=3.11 (1.16; 8.32) & 0.03 \\
\hline & & & 28 & $24 / 30(80)$ & $33 / 49(67)$ & OR=1.94 (0.66; 5.69) & 0.30 \\
\hline & \multirow{12}{*}{$\begin{array}{l}\text { Depending on } \\
\text { baseline score of the } \\
\text { ordinal scale }\end{array}$} & \multirow[t]{4}{*}{$3-4$} & 7 & $1 / 48(2.1)$ & $6 / 96(6.3)$ & $\mathrm{OR}=0.32(0.04 ; 2.73)$ & 0.42 \\
\hline & & & 14 & $22 / 48(46)$ & $39 / 96(41)$ & $\mathrm{OR}=1.23(0.62 ; 2.49)$ & 0.60 \\
\hline & & & 21 & $43 / 48(90)$ & $70 / 96(73)$ & OR=3.19 (1.14; 8.95) & 0.03 \\
\hline & & & 28 & $46 / 48(96)$ & $84 / 96(88)$ & $\mathrm{OR}=3.28(0.71 ; 15.32)$ & 0.14 \\
\hline & & \multirow[t]{4}{*}{5} & 7 & $1 / 64(1.6)$ & $4 / 106(3.8)$ & $\mathrm{OR}=0.41(0.04 ; 3.70)$ & 0.65 \\
\hline & & & 14 & $28 / 64(44)$ & $46 / 106(43)$ & $\mathrm{OR}=1.01(0.54 ; 1.90)$ & 1.00 \\
\hline & & & 21 & $54 / 64(84)$ & $74 / 106(70)$ & OR=2.33 $(1.06 ; 5.16$ & 0.04 \\
\hline & & & 28 & $58 / 64(91)$ & $85 / 106(80)$ & $\mathrm{OR}=2.39(0.91 ; 6.28)$ & 0.08 \\
\hline & & \multirow[t]{4}{*}{$6-7$} & 7 & $0 / 10(0)$ & $1 / 9(11)$ & $\mathrm{OR}=0.27(0.01 ; 7.51)$ & 0.47 \\
\hline & & & 14 & $6 / 10(60)$ & $2 / 9(22)$ & $\mathrm{OR}=5.25(0.70 ; 39.48)$ & 0.17 \\
\hline & & & 21 & $8 / 10(80)$ & $5 / 9(56)$ & $\mathrm{OR}=3.20(0.42 ; 24.4)$ & 0.35 \\
\hline & & & 28 & $9 / 10(90)$ & $6 / 9(67)$ & $\mathrm{OR}=4.50(0.37 ; 54.16)$ & 0.30 \\
\hline \multirow{2}{*}{$\begin{array}{l}\text { Deaths, } \mathrm{n} / \mathrm{N} \\
(\%)\end{array}$} & \multicolumn{2}{|l|}{ All patients } & - & $5 / 122(4.1)$ & $17 / 211(8.1)$ & $\mathrm{OR}=0.49(0.18 ; 1.34)$ & 0.18 \\
\hline & \multicolumn{2}{|l|}{$\mathrm{SpO}_{2} \leq 95 \%$} & - & $4 / 82(4.9)$ & $14 / 119(35.2)$ & $\mathrm{OR}=0.39(0.12 ; 1.21)$ & 0.13 \\
\hline \multirow{7}{*}{$\begin{array}{l}\text { No clinical } \\
\text { improvement } \\
\text { ( } \geq 2 \text { points } \\
\text { decrease) } \\
\text { within } 28 \\
\text { days, } \mathrm{n} / \mathrm{N}(\%)\end{array}$} & \multicolumn{2}{|l|}{ All patients } & \multirow[t]{7}{*}{28} & 9/122 (7.4) & $36 / 211(17)$ & $\mathrm{OR}=0.39(0.18 ; 0.84)$ & 0.01 \\
\hline & \multirow[t]{3}{*}{ Depending on $\mathrm{SpO}_{2}$} & $>95 \%$ & & $1 / 38(2.6)$ & $4 / 83(4.8)$ & $\mathrm{OR}=0.53(0.05 ; 4.94)$ & 1.00 \\
\hline & & $91-95 \%$ & & $2 / 52(3.8)$ & $12 / 20(17)$ & OR=0.03 $(0.005 ; 0.14)$ & $\begin{array}{l}<0.00 \\
1\end{array}$ \\
\hline & & $\leq 90 \%$ & & $6 / 30(20)$ & $16 / 49(33)$ & $\mathrm{OR}=0.52(0.18 ; 1.51)$ & 0.30 \\
\hline & Depending on & $3-4$ & & $2 / 48(4.2)$ & $12 / 96(13)$ & $\mathrm{OR}=0.30(0.07 ; 1.42)$ & 0.14 \\
\hline & baseline score of the & 5 & & $6 / 64(9.4)$ & $21 / 106(20)$ & $\mathrm{OR}=0.42(0.16 ; 1.10)$ & 0.08 \\
\hline & ordinal scale & $6-7$ & & $1 / 10(10)$ & $3 / 9(33)$ & $\mathrm{OR}=0.22(0.02 ; 2.67)$ & 0.30 \\
\hline The need of cor & stant oxygen therapy, $n$ & $\mathrm{~N}(\%)$ & - & $54 / 122(44)$ & $107 / 211(51)$ & OR $=0.77(0.49 ; 1.21)$ & 0.31 \\
\hline Duration of oxys & en therapy, mean $\pm S D$ & & - & $10.2 \pm 6.6$ & $12.1 \pm 11.2$ & - & 0.72 \\
\hline The need of me & hanical ventilation, $n / N$ & (\%) & - & $7 / 122(5.7)$ & $18 / 211(8.5)$ & $\mathrm{OR}=0.65(0.27 ; 1.61)$ & 0.39 \\
\hline Hospitalization & All patients & & - & $15.6 \pm 6.6$ & $18.1 \pm 10.4$ & - & 0.07 \\
\hline duration, & Depending on $\mathrm{SpO}_{2}$ & $>95 \%$ & - & $14.6 \pm 4.7$ & $15.7 \pm 6.2$ & - & 0.61 \\
\hline mean $\pm S D$ & & $91-95 \%$ & & $15.2 \pm 6.7$ & $16.6 \pm 9.0$ & - & 0.30 \\
\hline (dead were & & $\leq 90 \%$ & & $17.5 \pm 8.2$ & $25.0 \pm 14.7$ & - & 0.03 \\
\hline excluded) & Depending on & $3-4$ & & $14.3 \pm 5.2$ & $17.0 \pm 9.2$ & - & 0.12 \\
\hline & baseline score of the & 5 & & $16.2 \pm 7.3$ & $18.8 \pm 11.4$ & - & 0.26 \\
\hline & ordinal scale & $6-7$ & & $17.9 \pm 6.7$ & $21.7 \pm 8.7$ & - & 0.52 \\
\hline $\begin{array}{l}\text { Positive result o } \\
\text { hospitalization, }\end{array}$ & $\begin{array}{l}\text { RT-PCR after } 30 \text { days } \\
/ \mathrm{N}(\%)\end{array}$ & & 30 & $5 / 122(4.1)$ & $19 / 211(9)$ & $\mathrm{OR}=0.43(0.16 ; 1.19)$ & 0.12 \\
\hline $\begin{array}{l}\text { Adverse } \\
\text { events, } n / N\end{array}$ & Any adverse events & & - & $24 / 122(20)$ & $83 / 211(39)$ & OR=0.38 $(0.22 ; 0.64)$ & $\begin{array}{l}<0.00 \\
1\end{array}$ \\
\hline & Diarrhoea & & & $0 / 122(0.0)$ & $53 / 211(25)$ & OR=0.01 $(0.001 ; 0.20)$ & $\begin{array}{l}<0.00 \\
1\end{array}$ \\
\hline & Increase of aminotran & ferases & & $12 / 122(9.8)$ & $6 / 211(2.8)$ & OR=3.73 $(1.36 ; 10.20)$ & 0.01 \\
\hline & Nausea & & & $2 / 122(1.6)$ & $18 / 211(8.5)$ & OR=0.57 (0.11; 2.87) & 0.01 \\
\hline & Vomiting & & & $1 / 122(0.8)$ & $13 / 211(6.2)$ & $\mathrm{OR}=0.13(0.02 ; 0.97)$ & 0.01 \\
\hline & Prolongation of the $\mathrm{Q}$ & interval & & $0 / 122(0.0)$ & $11 / 211(5.2)$ & $\mathrm{OR}=0.07(0.004 ; 1.22)$ & 0.008 \\
\hline
\end{tabular}


medRxiv preprint doi: https://doi.org/10.1101/2020.10.30.20215301; this version posted November 3, 2020. The copyright holder for this preprint (which was not certified by peer review) is the author/funder, who has granted medRxiv a license to display the preprint in It is made available under a CC-BY-NC-ND 4.0 International license .

\section{Table 3}

Results of the logistic regression model for improvement according to the ordinal scale, defined as $\geq 2$ point decrease between baseline and day 21 of hospitalization in patients receiving RDV.

\begin{tabular}{|l|l|l|l|l|}
\hline & Estimate of $\beta$ & SE & tStat & pValue \\
\hline (Intercept) & 4.1063 & 0.7743 & 5.3033 & $1.1372 \mathrm{e}-07$ \\
\hline RDV (0/1) & 1.5014 & 0.37524 & 4.0012 & $6.3016 \mathrm{e}-05$ \\
\hline Tocilizumab (0/1) & -4.9421 & 1.644 & -3.0061 & 0.0026459 \\
\hline Age (per year) & -0.051216 & 0.012446 & -4.1152 & $3.8681 \mathrm{e}-05$ \\
\hline TOC:Age & 0.063616 & 0.02631 & 2.4179 & 0.015608 \\
\hline
\end{tabular}

Chi^2-statistic vs. constant model: $45.5, \mathrm{p}$-value $=3.1 \mathrm{e}-09, \mathrm{BIC}=310.29$ 
medRxiv preprint doi: https://doi.org/10.1101/2020.10.30.20215301; this version posted November 3, 2020. The copyright holder for this preprint (which was not certified by peer review) is the author/funder, who has granted medRxiv a license to display the preprint in It is made available under a CC-BY-NC-ND 4.0 International license .

\section{Figure 1}

\section{Categories of ordinal scale established in following time-points in patients treated with either remdesivir or ledipasvir/ritonavir based regimens.}

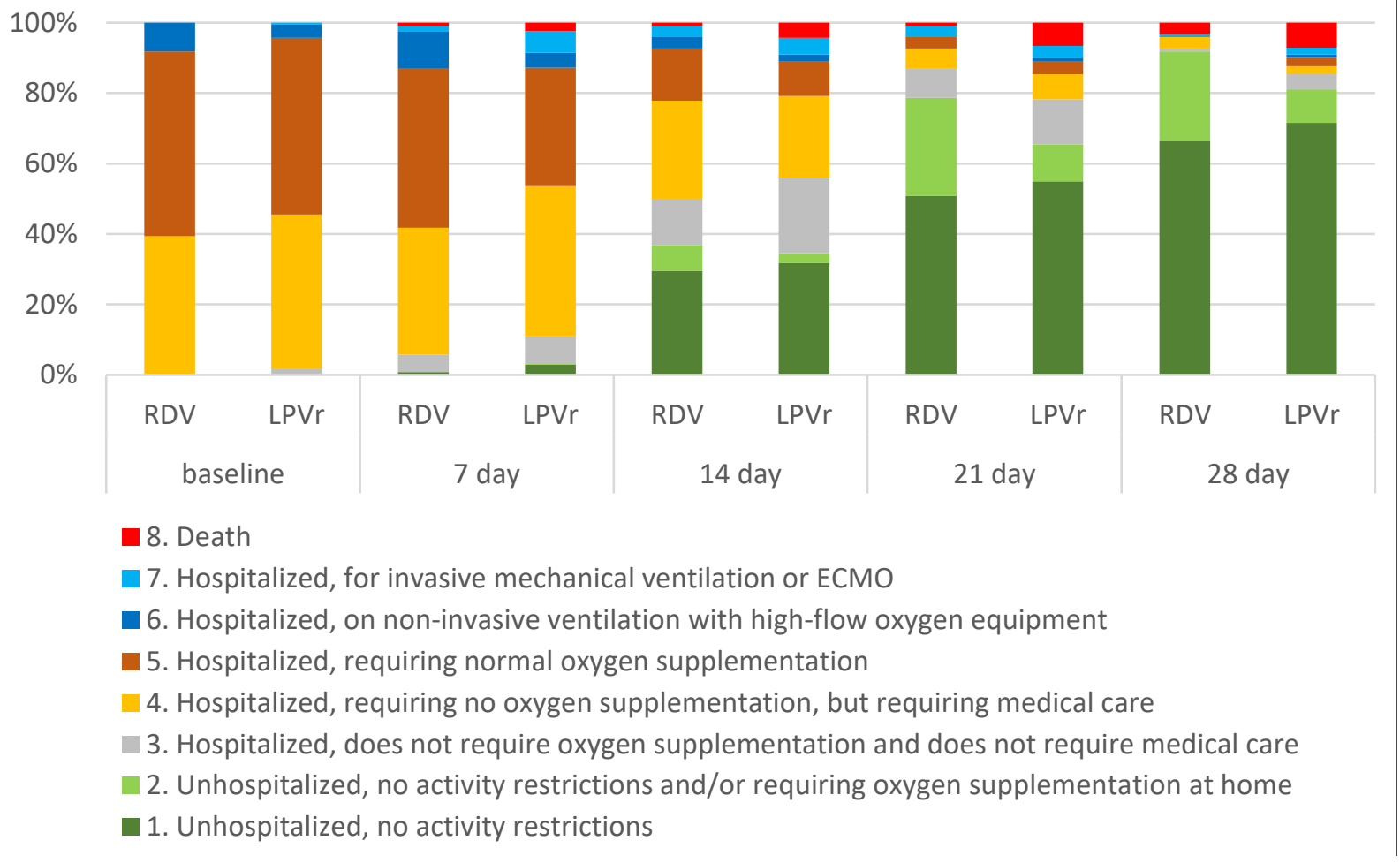


medRxiv preprint doi: https://doi.org/10.1101/2020.10.30.20215301; this version posted November 3, 2020. The copyright holder for this preprint (which was not certified by peer review) is the author/funder, who has granted medRxiv a license to display the preprint in It is made available under a CC-BY-NC-ND 4.0 International license .

\section{Figure 2}

Changes in the scoring of the ordinal scale at subsequent observation time points compared to baseline.

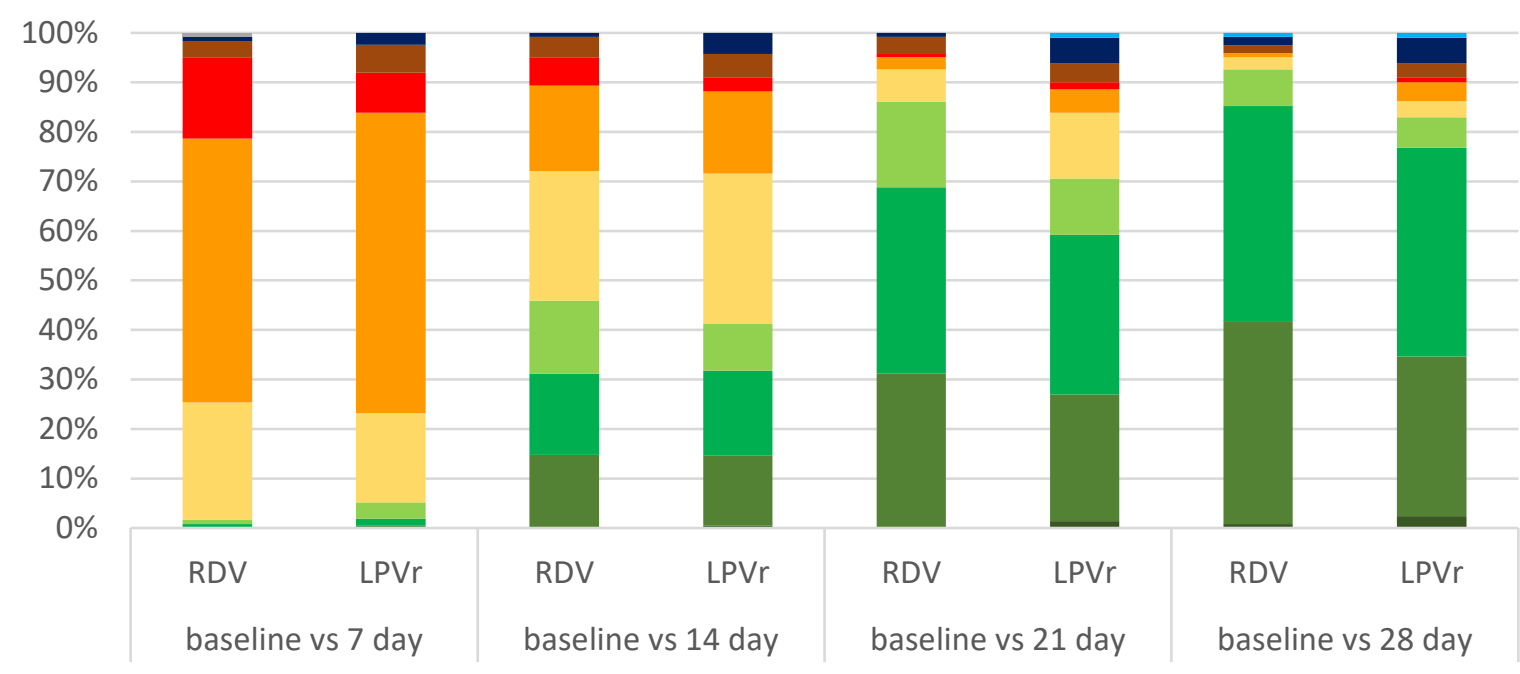

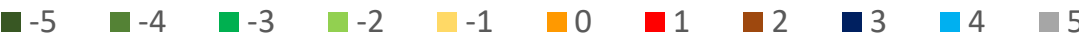

